\title{
Influence of some environmental conditions on stability and activity of Bacillus thuringiensis formulations against the cotton leaf worm, Spodoptera littoralis (Boisd.) (Lepidoptera: Noctuidae)
}

\author{
Moataz A. M. Moustafa ${ }^{1 *}$, Mohammed A. Saleh², Izat R. Ateya ${ }^{2}$ and Mohamed A. Kandil ${ }^{1}$
}

\begin{abstract}
The entomopathogenic bacterium Bacillus thuringiensis (Bt) has been used in crop protection for the last 70 years; however, many environmental conditions affect its activity. The present study was directed to evaluate the influence of certain environmental conditions on stability and activity of Bt samples of the two commercial formulations (Dipel $2 \times 6$. 4\% WP and Protecto 9.4\% WP), when stored under accelerated hot storage, shelf, and outdoor storage. Photo degradation of the two formulations was studied in aqueous solution. The results revealed that the loss percentage of Protecto formulation was above the permissible limits of WHO specifications after 2 years of storage at ambient conditions and the thermal stability of the Bt was affected negatively depending on the storage periods. In accordance with this trend, the bioassay tests versus neonate and second instar larvae of the cotton leaf worm, Spodoptera littoralis (Boisd.) (Lepidoptera: Noctuidae), showed a decrease in toxicity of the formulations to (60\%) after storage at $35 \pm 2{ }^{\circ} \mathrm{C}$ for 12 weeks and about (70\%) after storage under sunlight for 2 days. Photolysis of aqueous solutions reduced the half-life of formulations by about 1-2 days. The stability of Bt should be evaluated prior to submission for registration as these products have showed less stability under storage at ambient conditions. The stakeholders and decision-makers can utilize these results and examine such products case by case.
\end{abstract}

Keywords: Bacillus thuringiensis, Shelf life, Photodegradation, Thermal stability, Spodoptera littoralis

\section{Background}

Bacillus thuringiensis $(B t)$ is one of the earliest developed entomopathogens and widely used as biopesticide. It produces insecticidal proteins ( $\delta$-endotoxins) which exhibit toxicity to many insect species belong to order Lepidoptera, Diptera, and Coleoptera. Recently, several gene coding for the insect toxins of $B t$ has been genetically incorporated into crop plants. These are referred to as Bt-crops representing (19\%) of all GMO (Genetically manipulated organism) crops worldwide (Raddadi et al. 2009; Leng et al. 2011).

\footnotetext{
* Correspondence: moataz.moustafa79@gmail.com

'Department of Economic Entomology and Pesticides, Faculty of Agriculture, Cairo University, 6 ElGamma street, Giza 12613, Egypt

Full list of author information is available at the end of the article
}

Shelf life of entomopathogens is often low, and there is a difficulty to achieve a viable product after 1 or 2 years under ambient conditions. As it is known that products based on natural molecules tend to be less stable than synthetic compounds, hence their residual effects are biodegradable (Gupta and Dikshit 2010; Villaverde et al. 2014). In addition, these products are not stable under natural environmental stresses such as temperature, ultra violet (UV) radiation, and sunlight. Radiation from sunlight or UV light is the main limitation that obviously reduced the potency of $B t$ crystals against different insect pests (Dunkle and Shasha 1988; Ignoffo 1992; Khorramvatan et al. 2014).

The present study was conducted to evaluate the stability and insecticidal activity for two formulations of $B t$, exposed to temperature, light, and aqueous solutions. 


\section{Material and methods Bio-insecticides}

Two formulations of Bacillus thuringiensis, subsp. kurstaki, were used, Dipel $2 \times$ formulation (6.4\% WP contain 23,000 international unit/mg) produced by Valent Corporation USA and Protecto formulation (9.4\% WP contain 23,000 international unit/mg) produced by Biocide Production Unit, Plant Protection Res. Institute, Agriculture Research Center, Giza, Egypt.

\section{Insect rearing and bioassays \\ Insect source}

Spodoptera littoralis larvae were obtained from the laboratory of pesticide, Cairo University, Egypt, that reared under a complete absence of insecticides (Eldefrawi et al. 1964).

\section{Bioassay}

Bioassay was carried out using the leaf dipping technique (Ahmed 2009). Five serial concentrations, calculated as an active ingredient, ranging from 500 to $8000 \mathrm{mg} / \mathrm{L}$, of the two tested formulations against the neonates and 2nd instar larvae of S. littoralis. The castor leaves were immersed in the aqueous solution of each concentration for $20 \mathrm{~s}$, with gentle agitation, and then allowed to dry under an airflow. After drying, two leaves were placed in each glass jars. Twenty-five larvae were released into each glass jar. Four replicates were used per concentration; each replicate contained 25 larvae. Leaves dipped in water served as control. All glass jars were kept under $25 \pm 2{ }^{\circ} \mathrm{C}$ and $\mathrm{RH} 65 \%$. After $24 \mathrm{~h}$ of exposure, castor leaves treated with the bio-insecticides concentrations were removed and fresh non-treated leaves were added successively for 3 days. Mortality rates, 24 and $96 \mathrm{~h}$ post-treatments, as well the natural mortality were recorded.

\section{Statistical analysis}

Abbott (1925) corrected mortality data for control response. The median lethal concentration ( $\mathrm{LC}_{50}$ value) was calculated according to Finney (1971), using the software 321,958 package Ldp lines analysis version 1.0. Toxicity index was calculated according to Sun (1950).

Toxicity index $=$

( $\mathrm{LC}_{50}$ of the most effective sample/LC $\mathrm{L}_{50}$ of the sample)

$$
\times 100
$$

\section{Physical studies \\ Storage tests}

The formulated samples were stored according to (CIPAC, handbook J 2000, MT 46.3) as follows:
1- Accelerated hot storage: At $72 \pm 2{ }^{\circ} \mathrm{C}$ for 3 days, 54 $\pm 2{ }^{\circ} \mathrm{C}$ for 14 days, and $35 \pm 2{ }^{\circ} \mathrm{C}$ for 12 weeks. Storage procedure for solid formulation (wettable powder (WP)) were completed as follows: 20 g were placed in the beaker and spread, without applying pressure, in a smooth even layer of constant thickness. A disk was placed on the surface of the sample in a beaker; which placed in oven at the specified temperature and for the defined period. At the end of the time, the beaker was removed from the oven, the disk taken off, then placed in a desiccator and allowed to cool at room temperature.

2- Shelf storage: Samples were kept in original packaging, away from direct sunlight in stores for 2 years.

3- Storage in outdoor: Packaged samples were exposed to direct sunlight for 2,7 , and 15 days, at $35 \pm 2{ }^{\circ} \mathrm{C}$ as the average of temperature.

\section{Aqueous photolysis}

Three different sources of water (Nile, ground, and drain water) were used in this test. These water samples were collected from Al-Bureejat Village (Beheira Governorate); physical and chemical properties for each source of water were determined and presented in Table 1 according to Lico et al. (1982) and Rice et al. (2012). Suspensions from the two $B t$ formulations were prepared by different concentrations from the three different sources of water according to Behle et al. (1997) and Naghavi et al. (2016) and placed in a clear bottle, which then exposed to direct sunlight for $1,2,4,24,72$, and $120 \mathrm{~h}$. Dominating atmospheric temperature ranged between 32 and $38{ }^{\circ} \mathrm{C}$. At the end of time, samples were collected and analyzed.

\section{Photo degradation by UV light}

To study the effect of UV light on samples, UV Japan lamp (technical specification: G13T8 tube, $30 \mathrm{~W}, 254 \mathrm{~nm}$ ) was inserted in a tightly locked wooden box and connected to an electrical source. The suspensions from the two $B t$ formulation samples were prepared in a clear bottle. These samples were exposed directly to UV light inside the box for 1, 2, and $4 \mathrm{~h}$ according to Talkhan et al. (2013) and Khorramvatan et al. (2014). At the end of time, samples were collected and analyzed.

\section{Preparation of samples for analyses Strain standard preparation of $\mathrm{Bt}$}

The standard strain of (Bacillus thuringiensis kurstaki) was collected from Microbiological Resources Centre (Cairo MIRCEN), Faculty of Agriculture, Ain Shams University, Egypt, in a solidified medium (DSM Medium 1), consisting of peptone $5 \mathrm{~g}$, meat extract $3 \mathrm{~g}$, agar $15 \mathrm{~g}$, and distilled water $1000 \mathrm{ml}$. Different concentrations 
Table 1 Physiochemical properties of water

\begin{tabular}{|c|c|c|c|}
\hline Parameter (s) & Nile water & Ground water & Drain water \\
\hline $\mathrm{pH}^{*}$ & 7.17 & 7.33 & 7.41 \\
\hline Conductivity $\mathrm{Ms}^{*}$ & 463 & 775 & 787 \\
\hline Salinity \%* & 0.2 & 0.4 & 0.4 \\
\hline $\begin{array}{l}\text { Total dissolved solids } \\
\text { (TDS) } \mathrm{mg} / \mathrm{l}^{*}\end{array}$ & 219 & 370 & 378 \\
\hline \multicolumn{4}{|l|}{ Elements $(\mathrm{ppb})^{* *}$} \\
\hline $\mathrm{Cr}$ & N.D & N.D & N.D \\
\hline Co & N.D & 25 & 37 \\
\hline $\mathrm{Cu}$ & N.D & N.D & N.D \\
\hline $\mathrm{Fe}$ & N.D & N.D & N.D \\
\hline $\mathrm{Mn}$ & 41 & 49 & 48 \\
\hline $\mathrm{Ni}$ & 33 & 40 & 45 \\
\hline $\mathrm{Zn}$ & N.D & 35 & N.D \\
\hline Sn & 29 & 33 & 42 \\
\hline $\mathrm{Cd}$ & N.D & N.D & N.D \\
\hline $\mathrm{Pb}$ & N.D & N.D & N.D \\
\hline $\mathrm{Sb}$ & 0.9 & 0.88 & 0.97 \\
\hline As & N.D & N.D & N.D \\
\hline
\end{tabular}

*Determination was conducting according to Lico et al. (1982)

**Elements determination were carried out by using method of Rice et al. (2012)

were prepared to determine the $\mathrm{LC}_{50}$ according to Dulmage et al. (1971), Dulmage (1973), Navon et al. (1990), and Asan et al. (1993) in Agricultural Genetic Engineering Research Institute (AGERI), Agricultural Research Center, Giza, Egypt.

\section{Preparation of $B t$ formulations samples}

Suspensions from the two $B t$ formulations were prepared by different concentrations (ranging from 0.98 to $2000 \mathrm{mg}$ / 1). The bioassay test was used to evaluate the active ingredient, and the samples exposed to UV and sunlight.

\section{Determination the active ingredient of samples}

The determination method was based on the number of international units per milligram (IU/mg), using bioassay test and the calculation formula according to McLaughlin et al. (1984) as follows:
$\mathrm{IU} / \mathrm{mg}$ test sample $=\left(\mathrm{LC}_{50}\right.$ standard $/ \mathrm{LC}_{50}$ sample $)$ $\times$ potency of the standard in $\mathrm{IU} / \mathrm{mg}$.

The bioassay method described by Dulmage et al. (1971) was conducted by preparing artificial diet composed of dry kidney beans, dry yeast, dry agar, ascorbic acid, Nipagin, formalin, and water. After preparing the different concentrations of samples as mentioned above, they decanted in cups and kept at room temperature in a cap for $1 \mathrm{~h}$ to allow water to evaporate and condense. Ten neonate larvae of $S$. littoralis were placed into each cup. Three replicates were used for each concentration; each replicate contained ten larvae. A cup dipped in water served as control. All cups were kept at $25 \pm 2{ }^{\circ} \mathrm{C}$ and $\mathrm{RH}$ of $65 \%$. Mortality was recorded 24, 48, 72, and $96 \mathrm{~h}$ post-treatment and corrected for natural mortality by Abbott formula (Abbott 1925). LC L $_{50}$ values were calculated the according to Finney (1971).

\section{Kinetic study}

To study the rate of degradation of the tested bio-insecticide, the half-life time (T1/2) was calculated. The following equation according to Moye et al. (1987) was used:

$$
\begin{aligned}
\mathrm{T} 1 / 2 & =0.693 / \mathrm{K}, \text { where } K=\text { rate of degradation, } K \\
& =1 / \mathrm{Tx} . \ln \mathrm{a} / \mathrm{bx}
\end{aligned}
$$

where $\mathrm{Tx}=$ time in days or hours, $\mathrm{a}=$ initial residue, and $\mathrm{bx}=$ Residue at time.

\section{Results and discussion}

Effect of storage under accelerated hot storage and shelf life

The data presented in Table 2 indicated that the percentage of loss at $72 \pm 2{ }^{\circ} \mathrm{C}$ for 3 days was higher than storage at $54 \pm 2{ }^{\circ} \mathrm{C}$ for 14 days and $35 \pm 2{ }^{\circ} \mathrm{C}$ for 12 weeks. The loss \% was $13.42,3.41$, and $5.82 \%$ after storage at $72 \pm 2{ }^{\circ} \mathrm{C}$ for 3 days, $54 \pm 2{ }^{\circ} \mathrm{C}$ for 14 days, and $35 \pm 2{ }^{\circ} \mathrm{C}$ for 12 weeks, respectively, for Dipel $2 \times$ formulation. However, the formulation of Protecto was less stable, when stored at different temperatures, where the loss percentage was (13.93, 8.03, and $12.52 \%$ ) after storage at $72 \pm 2{ }^{\circ} \mathrm{C}$ for 3 days, $54 \pm 2{ }^{\circ} \mathrm{C}$ for 14 days, and $35 \pm 2{ }^{\circ} \mathrm{C}$ for 12 weeks,

\begin{tabular}{|c|c|c|c|c|}
\hline \multirow[t]{3}{*}{ Temperature/time } & \multicolumn{4}{|l|}{ Bacillus thuringiensis } \\
\hline & \multicolumn{2}{|l|}{ Dipel $2 \times$} & \multicolumn{2}{|l|}{ Protecto } \\
\hline & Content a.i IU/mg & Loss \% & Content a.i IU/mg & Loss $\%$ \\
\hline Zero time & 31,289 & 0 & 30,155 & 0 \\
\hline $72 \pm 2^{\circ} \mathrm{C}-3$ days & 27,089 & 13.42 & 25,955 & 13.93 \\
\hline $54 \pm 2^{\circ} \mathrm{C}-14$ days & 30,222 & 3.41 & 27,734 & 8.03 \\
\hline $35 \pm 2^{\circ} \mathrm{C}-12$ weeks & 29,156 & 5.82 & 26,379 & 12.52 \\
\hline
\end{tabular}

Table 2 Effect of storage under different temperatures on stability of Bacillus thurigiensis formulations 
Table 3 Effect of storage at ambient conditions for 2 years on stability of Bacillus thurigiensis formulations

\begin{tabular}{|c|c|c|c|c|}
\hline \multirow[t]{3}{*}{ Time } & \multicolumn{4}{|l|}{ Bacillus thuringiensis } \\
\hline & \multicolumn{2}{|l|}{ Dipel $2 x$} & \multicolumn{2}{|l|}{ Protecto } \\
\hline & Content a.i IU/mg & Loss $\%$ & Content a.i IU/mg & Loss $\%$ \\
\hline Zero time & 31,289 & 0 & 30,155 & 0 \\
\hline 3 months & 30,578 & 2.27 & 29,155 & 3.32 \\
\hline 6 months & 29,155 & 6.82 & 27,379 & 9.21 \\
\hline 24 months (2 years) & 26,665 & 14.79 & 23,372 & 22.49 \\
\hline
\end{tabular}

respectively. On the other hand, when the two formulations were stored for 2 years at room temperature, the losses were (14.79 and 22.49\%) for Dipel $2 \times$ and Protecto formulations, respectively (Table 3 ).

The permissible limit for loss at the stored bio-insecticide must be less than $16 \%$ of the active ingredient (WHO 2012). Although, the loss percentage for the two formulations was less than the permissible limit when stored under different temperatures. While for Protecto formulation stored for 2 years at room temperature, the loss percentage was higher than the permissible limit, while it was less than the permissible limit for Dipel $2 \times$ formulation. Therefore, the shelf life for Protecto formulation was less than 2 years. It was clear that these formulations had poor storage stability, where shelf life was often low and the viability of products did not exceed 2 years under ambient conditions. In addition, as known, the products based on natural molecules or contained natural active ingredients tend to be less stable than synthetic compounds (Gupta and Dikshit 2010; Villaverde et al. 2014). The results presented in Table 2 showed that temperature was one of the most important factors affecting degradation of the active ingredient during shelf or storage life. At storage temperatures of 35,54 , and $72{ }^{\circ} \mathrm{C}$, the high temperatures negatively affected the stability of $B t$, depending on storage periods. On the other hand, the low temperatures exhibited lightly effect. These results are in concinnity with Brar et al. (2005) and Sorokulova et al. (2008) who found that the temperature above $50{ }^{\circ} \mathrm{C}$ decreased the viability of spores and crystal protein. Ignoffo (1992) reported that the half-life of the toxin (Cry and Cyt) was less than 10 days at above $50{ }^{\circ} \mathrm{C}$ and the half-life of dry spores exposed at $50{ }^{\circ} \mathrm{C}$ was greater than 100 days. While wet spores had a half-life less than 60 days but those exposed at $60{ }^{\circ} \mathrm{C}$ were inactivated after an exposure of only $15 \mathrm{~min}$, in addition, the temperatures between 10 to $20{ }^{\circ} \mathrm{C}$ were considered optimal for spores activity and toxin effect.

\section{Effect of storage under sunlight}

Results in Table 4 show that the loss percentage of stored formulations Dipel $2 \times$ and Protecto, after exposure to direct sunlight for 15 days, were 34.90 and $45.99 \%$, respectively. It is observable from the data presented in Tables 2 , 3 and 4 that temperature and exposure to sunlight also affected negatively on their stability. The results showed that the loss percentage of the active ingredients proportionally increased after exposure to direct sunlight. Protecto was less stable to different storage conditions than Dipel $2 \times$. These results are in line with Ignoffo (1992) who found that spore viability of $B t$ was reduced by $50 \%$ after $30 \mathrm{~min}$ exposure to simulated sunlight. However, both formulations significantly been affected when stored under direct sunlight. In contrast, only the Dipel $2 \times$ formulation was more stable when stored away from sunlight and their shelf life may increase to 2 years.

\section{Bioassays and determination of lethal concentrations}

The lethal activities of Dipel $2 \times$ and Protecto formulations at different storage conditions including storage at $35 \pm 2{ }^{\circ} \mathrm{C}$ for 12 weeks and storage under direct sunlight for 2 days against the neonate and 2nd instar larvae of $S$. littoralis are given in Table 5 . Based on these results, the $\mathrm{LC}_{50}$ of the Dipel $2 \times$ formulation showed clear differences between $\mathrm{LC}_{50}$ values before and after storage under temperature of $35 \pm 2{ }^{\circ} \mathrm{C}$ and under sunlight to 3.3 and 3.6 fold, respectively. In addition, the $\mathrm{LC}_{50}$ values were 2.2 and 4.3 fold at $35 \pm 2{ }^{\circ} \mathrm{C}$ for 12 weeks and 2 days under sunlight, respectively for second instar larvae. Similarly, Protecto formulation, $\mathrm{LC}_{50}$ values for neonate larvae at $35 \pm 2{ }^{\circ} \mathrm{C}$ for 12 weeks and 2 days under sunlight were 2.6 and 2.8 fold, respectively, and for 2nd Instar larvae were 2.6 and 3.2 fold at $35 \pm 2{ }^{\circ} \mathrm{C}$ for 12 weeks and 2 days under sunlight, respectively.

\section{Aqueous stability}

Most bio-pesticide formulations are sold in concentrated form and have to be diluted in water before they can be applied. Stability of aqueous solution of bio-insecticides

Table 4 Effect of storage under direct sunlight on stability of Bacillus thurigiensis formulations

\begin{tabular}{|c|c|c|c|c|}
\hline \multirow[t]{3}{*}{ Time } & \multicolumn{4}{|l|}{ Bacillus thuringiensis } \\
\hline & \multicolumn{2}{|l|}{ Dipel $2 \times$} & \multicolumn{2}{|l|}{ Protecto } \\
\hline & Content a.i IU/mg & Loss \% & Content a.i IU/mg & Loss $\%$ \\
\hline Zero time & 29,155 & 0 & 28,311 & 0 \\
\hline 2 days & 24,889 & 14.63 & 23,610 & 16.60 \\
\hline 7 days & 21,689 & 25.61 & 19,789 & 30.10 \\
\hline 15 days & 18,979 & 34.90 & 15,289 & 45.99 \\
\hline
\end{tabular}


Table 5 Activity of Bacillus thuringiensis formulations against neonate and 2nd larvae of Spodoptera littoralis at different storage conditions

\begin{tabular}{|c|c|c|c|c|c|c|}
\hline Bioinsecticides & Conditions & $\mathrm{LC}_{50}(\mathrm{mg} / \mathrm{L})$ & $\mathrm{LC}_{90}(\mathrm{mg} / \mathrm{L})$ & $x^{2}$ & Slope \pm SE & Toxicity index \\
\hline \multicolumn{7}{|l|}{ Neonate larvae } \\
\hline \multirow[t]{3}{*}{ Dipel $2 x$} & 0 & 948.18 & 9067.25 & 3.37 & $1.307 \pm 0.12$ & 100 \\
\hline & 1 & 3156.95 & $24,948.50$ & 4.53 & $1.428 \pm 0.16$ & 30.03 \\
\hline & 2 & 3460.22 & $28,855.13$ & 2.86 & $1.391 \pm 0.22$ & 27.40 \\
\hline \multirow[t]{3}{*}{ Protecto } & 0 & 1577.92 & $33,715.81$ & 1.16 & $0.935 \pm 0.11$ & 100 \\
\hline & 1 & 4233.44 & $37,038.06$ & 1.07 & $1.422 \pm 0.19$ & 37.27 \\
\hline & 2 & 4504.29 & $38,769.82$ & 2.88 & $1.371 \pm 0.19$ & 35.03 \\
\hline \multicolumn{7}{|l|}{ 2nd larvae } \\
\hline \multirow[t]{3}{*}{ Dipel $2 x$} & 0 & 931.99 & $17,905.98$ & 6.97 & $0.998 \pm 0.11$ & 100 \\
\hline & 1 & 2069.06 & $10,281.37$ & 1.26 & $1.841 \pm 0.12$ & 45.04 \\
\hline & 2 & 4067.42 & $24,013.61$ & 8.34 & $1.662 \pm 0.19$ & 22.91 \\
\hline \multirow[t]{3}{*}{ Protecto } & 0 & 1530.31 & $59,547.43$ & 0.56 & $0.806 \pm 0.11$ & 100 \\
\hline & 1 & 4051.99 & $25,819.24$ & 6.67 & $1.593 \pm 0.19$ & 37.77 \\
\hline & 2 & 5000.50 & $71,826.85$ & 1.02 & $1.107 \pm 0.22$ & 30.60 \\
\hline
\end{tabular}

0-zero time where each mg contain 31,289 IU for Dipel $2 \times$ and 30,155 IU for Protecto

1 -storage at $35 \pm 2{ }^{\circ} \mathrm{C}$ for 12 weeks where each mg contain 29,156 IU for Dipel $2 \times$ and 26,379 IU for Protecto

2-storage under direct sunlight for 2 days where each mg contain 24,889 IU for Dipel $2 \times$ and 23,610 IU for Protecto

Table 6 Effect of photolysis in water for Bacillus thuringiensis formulations

\begin{tabular}{|c|c|c|c|c|c|c|c|}
\hline \multirow[t]{3}{*}{ Bioinsecticides } & \multirow[t]{3}{*}{ Time/hours } & \multicolumn{6}{|c|}{ Water source } \\
\hline & & \multicolumn{2}{|c|}{ Nile water } & \multicolumn{2}{|c|}{ Ground water } & \multicolumn{2}{|c|}{ Drain water } \\
\hline & & $\mathrm{IU} / \mathrm{mg}$ & Loss \% & $\mathrm{IU} / \mathrm{mg}$ & Loss \% & $\mathrm{IU} / \mathrm{mg}$ & Loss $\%$ \\
\hline \multirow[t]{7}{*}{ Dipel $2 x$} & 0 & 28,834 & 0 & 28,376 & 0 & 28,376 & 0 \\
\hline & 1 & 27,965 & 3.01 & 27,644 & 2.58 & 27,920 & 1.61 \\
\hline & 2 & 26,920 & 6.64 & 26,834 & 5.43 & 26,844 & 5.40 \\
\hline & 4 & 25,400 & 11.91 & 25,465 & 10.26 & 25,320 & 10.77 \\
\hline & 24 & 20,200 & 29.94 & 20,320 & 28.39 & 18,844 & 33.59 \\
\hline & 72 & 13,712 & 52.44 & 13,200 & 53.48 & 13,010 & 54.15 \\
\hline & 120 & 11,100 & 61.50 & 11,134 & 60.76 & 10,844 & 61.78 \\
\hline \multicolumn{2}{|c|}{ Regression equation (y =) } & \multicolumn{2}{|c|}{$-0.0185 x+10.19$} & \multicolumn{2}{|c|}{$-0.0162 x+10.19$} & \multicolumn{2}{|c|}{$-0.0153 x+10.18$} \\
\hline \multicolumn{2}{|c|}{ Degradation rate $(\mathrm{K})$} & \multicolumn{2}{|c|}{0.01853} & \multicolumn{2}{|l|}{0.01621} & \multicolumn{2}{|c|}{0.01527} \\
\hline \multicolumn{2}{|l|}{$t_{1 / 2} h$} & \multicolumn{2}{|l|}{37.40} & \multicolumn{2}{|l|}{42.76} & \multicolumn{2}{|l|}{45.40} \\
\hline \multicolumn{2}{|c|}{ Determination coefficient $\left(R^{2}\right)$} & \multicolumn{2}{|l|}{0.97} & \multicolumn{2}{|l|}{0.96} & \multicolumn{2}{|l|}{0.94} \\
\hline \multirow[t]{7}{*}{ Protecto } & 0 & 27,560 & 0 & 27,560 & 0 & 27,560 & 0 \\
\hline & 1 & 26,245 & 4.77 & 26,263 & 4.71 & 26,400 & 4.21 \\
\hline & 2 & 24,710 & 10.34 & 24,534 & 10.98 & 24,821 & 9.94 \\
\hline & 4 & 23,400 & 15.09 & 23,279 & 15.53 & 23,144 & 16.02 \\
\hline & 24 & 18,555 & 32.67 & 18,979 & 31.14 & 17,910 & 35.01 \\
\hline & 72 & 12,310 & 55.33 & 12,266 & 55.49 & 12,200 & 55.73 \\
\hline & 120 & 9117 & 66.92 & 9355 & 66.06 & 8934 & 67.58 \\
\hline \multicolumn{2}{|c|}{ Regression equation ( $y=$ ) } & \multicolumn{2}{|c|}{$-0.0259 x+10.13$} & \multicolumn{2}{|c|}{$-0.0263 x+10.13$} & \multicolumn{2}{|c|}{$-0.0254 x+10.13$} \\
\hline \multicolumn{2}{|c|}{ Degradation rate $(K)$} & \multicolumn{2}{|c|}{0.02589} & \multicolumn{2}{|l|}{0.02632} & \multicolumn{2}{|l|}{0.02537} \\
\hline \multicolumn{2}{|l|}{$t_{1 / 2} h$} & 26.77 & & 26.33 & & 27.32 & \\
\hline Determination & $\left(R^{2}\right)$ & 0.98 & & 0.98 & & 0.97 & \\
\hline
\end{tabular}


depends upon the source of water and the exposure period to sunlight. Naturally, the various sources of water are different in their physiochemical properties and this may be reflected on stability of the tested bio-insecticides. Data presented in Table 6 subjected to first-order kinetics, using regression analysis, where the regression equations and half-life values $t_{1 / 2}$ along with determination coefficient and degradation rate $K$ values, for Dipel $2 \times$ and Protecto formulations, were calculated. The results showed that samples exposed to sunlight for after $120 \mathrm{~h}$ in different sources of water, loss more than 60 and $65 \%$ of its concentrations for Dipel $2 \times$ and Protecto, respectively. Tested bio-insecticides dissipated faster after exposure to sunlight in different sources of water, where the half-life of $B t$ was 1-2 days. Previous studies reported that aqueous photolysis of $B t$ was rapid and observed half-lives of endotoxin was from 1 to 4 days (Ignoffo 1992). As the spore viability was reduced by $(80 \%)$ after exposure to natural sunlight for 1 day after application, while it reduced (50\%) after 30 min exposure to simulated sunlight in filter and glass tube. In addition, endotoxin activity was reduced, but it required about eight times more sunlight exposure ( $3.8 \mathrm{~h})$ to obtain a $50 \%$ loss in insecticidal activity. Behle et al. (1997) found that the activity of $B t$ formulations decreased about $20 \%$ after exposure to sunlight for 1 day, about $35 \%$ after 2 days and more than $80 \%$ after 7 days. Recently, Naghavi et al. (2016) noticed that the activity of $B t$ formulations decreased about $40 \%$ after exposure to sunlight for 3 days, and more than $50 \%$ after 7 days and no activity after 10 days. Data observed that the photolysis in water played a vital role in the degradation of the tested bio-insecticides. However, amount of samples kept away from sunlight for 5 days had not changed and remained stable as it was without any loss of its concentration.

\section{Photo degradation under UV light}

The data presented in Table 7 showed that after $8 \mathrm{~h}$ of exposing, more than $55 \%$ of concentrations of the two formulations were dissipated, where the half-life was 7.97 and $6.31 \mathrm{~h}$ of Dipel $2 \times$ and Protecto, respectively. Several studies investigated the role of UV light on degradation of $B t$ formulations. Cohen et al. (1991) tested the effect of ultraviolet irradiation at $300-350 \mathrm{~nm}$ of $B t$ where its activity decreased to 70 and $95 \%$, after 6 and $12 \mathrm{~h}$ from irradiation, respectively. Khorramvatan et al. (2014) found that the activity of $B t$ decreased to 50 and $40 \%$, respectively after $1 \mathrm{~h}$ from exposing to ultraviolet irradiation at 245 and $385 \mathrm{~nm}$. Moreover, the same authors found that the addition of UV protectants could reduce photo degradation and reported that addition of sodium alginate to $B t$ formulations decreased of UV effect, as also the degradation rate is changed by changing the concentration of solutions that exposed to UV light.
Table 7 Effect of exposed to UV light of the Bacillus thuringiensis formulations

\begin{tabular}{|c|c|c|c|c|}
\hline \multirow[t]{3}{*}{ Time/hour } & \multicolumn{4}{|c|}{ Bacillus thuringiensis } \\
\hline & \multicolumn{2}{|c|}{ Dipel $2 x$} & \multicolumn{2}{|c|}{ Protecto } \\
\hline & $\mathrm{IU} / \mathrm{mg}$ & Loss \% & $\mathrm{IU} / \mathrm{mg}$ & Loss \% \\
\hline 0 & 28,800 & 0 & 27,733 & 0 \\
\hline 1 & 26,667 & 7.41 & 24,533 & 11.54 \\
\hline 2 & 22,400 & 22.22 & 20,267 & 26.92 \\
\hline 4 & 17,066 & 40.74 & 16,000 & 42.31 \\
\hline 8 & 12,800 & 55.56 & 9600 & 65.38 \\
\hline Regression equation $\mathrm{y}=$ & \multicolumn{2}{|c|}{$-0.0870 x+10.25$} & \multicolumn{2}{|c|}{$-0.1098 x+10.22$} \\
\hline Degradation rate $(K)$ & \multicolumn{2}{|l|}{0.08697} & \multicolumn{2}{|c|}{0.10985} \\
\hline$t_{1 / 2} h$ & \multicolumn{2}{|l|}{7.97} & \multicolumn{2}{|l|}{6.31} \\
\hline Determination coefficient $\left(R^{2}\right)$ & \multicolumn{2}{|l|}{0.96} & \multicolumn{2}{|l|}{0.99} \\
\hline
\end{tabular}

\section{Conclusions}

The UV light and sunlight are a primary degradation pathway for this bio-insecticide and needs to be controlled. Likewise, the photolysis in water plays a vital role in the degradation of the tested bio-insecticides. The present study pointed out that the shelf life of the tested bio-insecticides is relatively short and does not exceed 2 years. Moreover, the tested bio-insecticides need to be stored in proper conditions in order to conserve their bioactivity. Finally, the growers and farmers could get benefit from data obtained regarding performance of the tested bio-pesticides under field conditions.

\section{Acknowledgements \\ We would like to thank the laboratory of pesticide section, Faculty of Agriculture, Cairo University; Agricultural Genetic Engineering Research Institute (AGERI); Agricultural Research center and Central of Agriculture Pesticides Laboratory (CAPL), Agriculture Research Center, Egypt, who supported this work. The authors are grateful to Dr. Fabio Veronesi (Harper Adams University, UK) for suggesting improvements to the manuscript.}

\section{Availability of data and materials}

All data of the study have been presented in the manuscript, and the materials, which are used in this study, are of high quality and grade.

\section{Authors' contributions}

The authors carried out all the experiments including the bioassay tests, analytical part, analysis of data and wrote the manuscript. All authors read and approved the final manuscript.

Ethics approval and consent to participate

Not applicable.

Consent for publication

This study does not contain any individual person's data.

Competing interests

The authors declare that they have no competing interests.

\section{Publisher's Note}

Springer Nature remains neutral with regard to jurisdictional claims in published maps and institutional affiliations. 


\section{Author details}

Department of Economic Entomology and Pesticides, Faculty of Agriculture, Cairo University, 6 ElGamma street, Giza 12613, Egypt. 'Department of Pesticides Analysis Researches, Central Agricultural Pesticides Laboratory, Agricultural Research Center, Dokki, Giza, Egypt.

Received: 18 May 2018 Accepted: 16 July 2018

Published online: 27 July 2018

\section{References}

Abbott WS (1925) A method for computing the effectiveness of an insecticide. J Econ Entomol 18:265-267

Ahmed M (2009) Observed potentiation between pyrethroid and organophosphorus insecticides for management of Spodoptera litura (Lepidoptera: Noctuidae). Crop Prot 28:264-268

Asan S, Maruyama T, Iwasa T, Seki A, Takahashi M, Soares JGG (1993) Evaluation of biological activity of Bacillus thuringiensis test samples using a diet incorporation method with diamondback moth, Plutella xylostella (Linnaeus) (Lepidoptera: Yponomeutidae). Appl Entomol Zool 28:513-524

Behle RW, McGuire MR, Shasha BS (1997) Effects of sunlight and simulated rain on residual activity of Bacillus thuringiensis formulations. J Econ Entomol 90: 1560-1566

Brar SK, Verma M, Tyagi RD, Valéro JR, Surampalli RY (2005) Starch industry wastewater-based stable Bacillus thuringiensis liquid formulations. J Econ Entomol 98:1890-1898

CIPAC, handbook J (2000) Collaborative international pesticides analytical Council limited. MT46.3 accelerated storage procedure, pp 128-130

Cohen E, Rozen H, Joseph T, Braun S, Margulies L (1991) Photoprotection of Bacillus thuringiensis kurstaki from ultraviolet irradiation. J Invertebr Pathol 57: 343-351

Dulmage HT (1973) Bacillus thuringiensis US assay standard: report on the adoption of a primary US reference standard for assay of formulations containing the $\delta$-endotoxin of Bacillus thuringiensis. Bull ESA 19:200-202

Dulmage HT, Boening OP, Rehnborg CS, Hansen GD (1971) A proposed standardized bioassay for formulations of Bacillus thuringiensis based on the international unit. J Invertebr Pathol 18:240-245

Dunkle RL, Shasha BS (1988) Starch-encapsulated Bacillus thuringiensis: a potential new method for increasing environmental stability of entomopathogens. Environ Entomol 17:120-126

Eldefrawi ME, Toppozada A, Mansour N, Zeid M (1964) Toxicological studies on the Egyptian cotton leaf worm, Prodenia litura. I. Susceptibility of different larval instars of Prodenia to insecticides. J Econ Entomol 57:591-593

Finney DJ (1971) Probit analysis. Cambridge Univ. Press, UK, p. 333

Gupta S, Dikshit AK (2010) Biopesticides: an ecofriendly approach for pest control. J Biopestic 3:186-188

Ignoffo CM (1992) Environmental factors affecting persistence of entomopathogens. Fla Entomol 75:516-525

Khorramvatan S, Marzban R, Ardjmand M, Safekordi A, Askary H (2014) The effect of polymers on the stability of microencapsulated formulations of Bacillus thuringiensis subsp. kurstaki (Bt-KD2) after exposure to ultra violet radiation. Biocontrol Sci Technol 24:462-472

Leng P, Zhang Z, Pan G, Zhao M (2011) Applications and development trends in biopesticides. Afr J Biotechnol 10:19864-19873

Lico MS, Kharaka YK, Carothers WW, Wright VA (1982) Methods for collection and analysis of geopressured geothermal and oil field waters. US Department of the Interior, Geological Survey, USA, p. 28

McLaughlin RE, Dulmage HT, Alls R, Couch TL, Dame DA, Hall IM, Versoi PL (1984) US standard bioassay for the potency assessment of Bacillus thuringiensis serotype $\mathrm{H}-14$ against mosquito larvae. Bull ESA 30:26-29

Moye HA, Malagodi MH, Yoh J, Leibee GL, Ku CC, Wislocki PG (1987) Residues of avermectin B1a in rotational crops and soils following soil treatment with [14C] avermectin B1a. J Agric Food Chem 35:859-864

Naghavi SS, Marzban R, Imani S (2016) Stability of Bacillus thuringiensis and NPV microencapsulated formulation under sunlight. Int J Adv Biotechnol Res 7: 2224-2230

Navon A, Klein M, Braun S (1990) Bacillus thuringiensis potency bioassays against Heliothis armigera, Earias insulana, and Spodoptera littoralis larvae based on standardized diets. J Invertebr Pathol 55:387-393

Raddadi N, Belaouis A, Tamagnini I, Hansen BM, Hendriksen NB, Boudabous A Daffonchio D (2009) Characterization of polyvalent and safe Bacillus thuringiensis strains with potential use for biocontrol. J Basic Microbiol 49: 293-303

Rice EW, Baird RB, Eaton AD, Clesceri LS (2012) Standard methods for the examination of water and wastewater. American Public Health Association, American Water Works Association, and Water Environment Federation Press, USA, p. 1496

Sorokulova IB, Krumnow AA, Pathirana S, Mandell AJ, Vodyanoy V (2008) Novel methods for storage stability and release of Bacillus spores. Biotechnol Prog 24:1147-1153

Sun YP (1950) Toxicity index-an improved method of comparing the relative 378 toxicity of insecticides. J Econ Entomol 43:45-53

Talkhan FN, Abo-assy HH, Azzam MM, Abdel-Razek AS (2013) Activity of deltaendotoxin protein crystals in Bacillus thuringiensis mutants when influenced by UV treatments. Arch Phytopathol Plant Protect 46:1346-1358

Villaverde JJ, Sevilla MB, Sandín EP, López GC, Alonso-Prados JL (2014) Biopesticides in the framework of the European Pesticide Regulation (EC) No. 1107/2009. Pest Manag Sci 70:2-5

WHO (2012) WHO Specification and Evaluation for Public Health pesticides. Bacillus thuringiensis subspecies israelensis strain AM65-52, p 52 http://www. who.int/whopes/quality/Bti_eval_spec_October_2012.pdf

\section{Submit your manuscript to a SpringerOpen ${ }^{\circ}$ journal and benefit from:}

- Convenient online submission

- Rigorous peer review

- Open access: articles freely available online

- High visibility within the field

- Retaining the copyright to your article

Submit your next manuscript at $>$ springeropen.com 